\title{
THE GENERA GYMNODORIS AND NEMBROTHA FROM JAPAN (NUDIBRANCHIA-POLYCERIDAE)
}

\author{
$\operatorname{AUTHOR}(\mathrm{S}):$ \\ Baba, Kikutaro
}

\section{CITATION:}

Baba, Kikutaro. THE GENERA GYMNODORIS AND NEMBROTHA FROM JAPAN

(NUDIBRANCHIA-POLYCERIDAE). PUBLICATIONS OF THE SETO MARINE BIOLOGICAL LABORATORY 1960, 8(1): 71-74

ISSUE DATE:

1960-05-30

URL:

http://hdl.handle.net/2433/174700

RIGHT: 


\title{
THE GENERA GYMNODORIS AND NEMBROTHA FROM JAPAN (NUDIBRANCHIA-POLYCERIDAE) ${ }^{13}$
}

\author{
KikUtAkô BABA \\ Biological Laboratory, Osaka Gakugei University \\ With Plate $V$
}

The two genera (Gymnodoris and Nembrotha) have recently been discussed by MACNAE (1959 ?, pp. 354-355). The hitherto recorded members of them from our territory and the adjacent waters are as below:

1. Gymnodoris bicolor (ALDER \& HANCOCK, 1864) =G. citrina (BERGH, 1877); G. japonica (BABA, 1930); ? G. maculata STIMPson, 1855 ${ }^{2}$ Kinuhada-modoki Loc. : Sagami Bay; Toba and Sugashima; Kii ; Osaka Bay; Inland Sea of Seto; Amakusa ; Asamushi ; Sado I. ; Toyama Bay ; Togi Kazanashi, W. coast of Noto Peninsula ; Tsuruga Bay;? Takarajima I. (Tokara group of S. Kyushu).

Dist.: E. Africa and Indian Ocean; N. Caledonia ; Palau Is.

2. Gymnodoris alba (BERGH, 1877) Akaboshi-umiushi

Loc. : Tateyama Bay; Sagami Bay; Sugashima near Toba; Kii.

Dist.: Indian Ocean; Philippines.

3. Gymnodoris inornata (BERGH, 1880) Kinuhada-umiushi

Loc. : Tateyama Bay; Sagami Bay; Kii ; Osaka Bay ; Amakusa ; Nagasaki. Dist.: E. Africa and ? E. Indies.

4. Gymnodoris striata (ELIOT, 1908) Kinsen-umiushi

Loc. : Inland Sea of Seto; Amakusa ; Toyama Bay. ${ }^{3)}$

5. Gymnodoris okinawae BABA, 1936 Okinawa-kinuhada-umiushi (n.n.)

Loc. : Okinawa (Riukiu) Is. (Ishigaki-jima).

6. Gymnodoris subflava BABA, 1949 Usuginu-umiushi

Loc. : Sagami Bay; Kii ; Inland Sea of Seto.

1) Contributions from the Seto Marine Biological Laboratory, No. 347.

2) Originally known from Okinawa (Riukiu), but not fully described. See MACNAE, 1959?, p. 354.

3) Our specimens from Japan appear to constitute a light colour variety of the typical striata, which occurs in the Suez Canal, Red Sea and New Caledonia. See BABA, 1937, pp. 216-218, figs. 1-2.

Publ. Seto Mar. Biol. Lab., VIII (1), 1960. (Article 7) 
7. Nembrotha gracilis BERGH, 1877 Ryugu-umiushi

Loc. : Sagami Bay; Kii.

Dist.: Philippines.

8. Nembrotha luteolineata BABA, 1936 Ishigaki-ryugu-umiushi (n.n.)

Loc. : Okinawa (Riukiu) Is. (Ishigaki-jima).

9. Nembrotha sagamiana $\mathrm{BABA}, 1955$ Sagami-ryugu-umiushi

Loc. : Sagami Bay.

This paper contains the following three species new to Japan.

\section{Gymnodoris nigricolor BABA, n. sp.}

\section{Sumizome-kinuhada-umiushi (n.n.)}

(Pl. V, Figs. 1A-1B)

Very distinct in colouring and in the shape of the radula teeth. Length $4 \mathrm{~mm}$. Body smooth. Gills small, consisting of 9 plumes arranged in a semicircle open behind. Back and sole uniformly bluish black; rhinophores and gills also bluish black. Radula formula $22 \times 7-8 \cdot 1 \cdot 0.1 .7-8$. First lateral broad and tricuspidate (the median cusp sharp, the lateral cusps blunt). Next laterals pyriform.

Loc.: Misaki, Sagami Bay, on $2 \mathrm{~m}$ bottom mud (Nov. 1956, $1 \mathrm{sp}$., coll. by the Biological Laboratory, Imperial Household).

The black colouring of this species is somewhat unusual in the genus Gymnodoris.

\section{Gymnodoris subornata BABA, n. sp.}

Hime-kinuhada-umiushi (n.n.)

(Pl. V, Figs. 2A-2C)

Especially marked by having a small, more or less rudimentary radula. Colouring somewhat as in G. inornata (BERGH, 1880). Body always small, 6-10 $\mathrm{mm}$ long; smooth, or sometimes with minute conical tubercles on the pallial margin ; gills small, formed of 3-8 plumes set in a semicircle; whole body surface deep orange-red, rhinophores and gills also orange-red. Radula always small, the representative formula being $16 \times 6.1 .0 .1 .6$. (Seto specimen). First lateral very small, or missing altogether. Next laterals roughly hamate, each with a straight hook.

Loc.: Seto, Kii (May 1954, 1 sp., coll. by Mr. Yамамото). Murotozaki, Shikoku (Apr. 1958, 1 sp.). Ogi, Toyama Bay (July 1953, 1 sp., coll. by Mr. ABE). Matsugazaki, Tsuruga Bay (July 1955, 2 sps., coll. by Mr. ABE). On shores. 


\section{Nembrotha limaciformis ELIOT, 1908}

Nishiki-ryugu-umiushi (n. n.)

(Pl. V, Figs. 3A-3D)

Nembrotha limaciformis ELIOT, 1908, pp. 98-99.-Red Sea.

The animal in bright colouring is like a species of Gymnodoris, but it has the radula type of Nembrotha. Length $18-20 \mathrm{~mm}$. Body smooth. Gills 3-5, bipinnate. Oral tentacles lobiform. General colour a deep saffron-red, the back and sides flecked with yellowish white or entirely plain; rhinophores saffron-red, sometimes having a subapical purple spot; gills yellowish white tipped always with purple. Sole uniformly saffron-red. No labial armatures. Radula formulae in three specimens collected : $8 \times 5.1 .1 .1 .5,8 \times 5-6.1 .1 .1 .5-6$, and $12 \times 6.1 .1 .1 .6$. Central tooth subquadrate, without hooks; first lateral large, simply hamate; outer laterals scalelike.

Loc.: Seto, Kii, on shore (June 1951 and May 1954, 3 sps., coll. by Mr. YAMAMOTO).

The purple spots on the rhinophores and on the gills are distinctive in this species, but they are not described in the closely allied form, $N$. divae Marcus, 1956, from Brazil.

Acknowledgements: I am greatly indebted to the following gentlemen by whom many of the specimens have been offered me for examination: Dr. Hirotaro HATtorI (Biological Laboratory of the Imperial Household); Mr. Torao YAmAмото (Seto Marine Biological Laboratory of the Kyoto University); Mr. Takeo AвE (Takaoka Senior High School of Toyama Pref.).

\section{REFERENCES}

ALDER, J. \& HANCOCK, A. 1864. Notice of a collection of nudibranchiate Mollusca made in India by Walter ElLIOT, Esq., with descriptions of several new genera and species. Trans. Linn. Soc. London, vol. 5 .

BABA, K. 1930. Studios on Japanese nudibranchs. 2. Venus, vol. 2, no. 2. (in Japanese) 1936. Opisthobranchia of the Ryûkyâ (Okinawa) Islands. Journ. Dept. Agric. Kyushu Imp. Univ., vol. 5, no. 1.

1937. Record of a nudibranch, Gymnodoris striata (ELIOT), from Amakusa, Japan. Dobutsugaku Zasshi (Zool. Mag.), vol. 49, no. 6. (in Japanese) 1949. Opisthobranchia of Sagami Bay. Iwanami Shoten, Tokyo. 1955. Opisthobranchia of Sagami Bay, Supplement. Ditto.

BERGH, R. 1877. Malacologische Untersuchungen, Hft. 11. 1880. Beiträge zur Kenntniss der japanischen Nudibranchien, I. Verh. k. k. zool.-bot. Gesell. Wien, Bd. 30.

ELIOT, C. 1908. Reports on the marine Biology of the Sudanese Red Sea. 11. Notes on a collection of nudibranchs from the Red Sea. Journ. Linn. Soc. London, Zool, vol. 31.

Macnae, W. 1959?. The families Polyceridae and Goniodorididae (Mollusca, Nudibranchiata) in Southern Africa. Trans. Roy. Soc. S. Africa, vol. 35, pt. 4.

MARCUS, E. 1956. Notes on Opisthobranchia. Bol. Inst. Oceanogr., tom. 7, fasc. 1-2.

STIMPSON, W. 1855. Descriptions of some of the new marine Invertebrata from the Chinese and Japanese seas. Proc. Acad. Nat. Sci. Philad., vol. 7. 


\section{EXPLANATION OF PLATE V}

Figs. 1A-1B. Gymnodoris nigricolor. 1A. Animal from Misaki, Sagami Bay (Nov. 27, 1956, length $4 \mathrm{~mm}$, original fig. taken by the Biological Laboratory, Imperial Household); 1B. A half-row of radula $(\times 260)$, a. 1st lateral, b. outermost laterals.

Figs. 2A-2C. Gymnodoris subornata. 2A. Animal from Seto, Kii (May 7, 1954 , length $6 \mathrm{~mm}$ ); 2B. A half-row of radula in the same specimen $(\times 350)$, a. 1st lateral, b. outermost laterals; 2 C. A half-row of radula in the specimen from Toyama Bay $(\times 250)$, letters as before.

Figs. 3A-3D. Nembrotha limaciformis. 3A. Animal from Seto, Kii (June 22 , 1951, length $18 \mathrm{~mm}$ ), body saffron-red with yellowish white markings; 3B. A half-row of radula in the same specimen $(\times 95)$, a. central tooth, b. 1st lateral, c. outer laterals; 3C. Animal from Seto (May 6, 1954, length $20 \mathrm{~mm}$ ), body uniformly saffron-red without markings; 3D. Radula teeth in the same specimen $(\times 60)$, a. central tooth, b. 1st lateral. 
Publ. Seto Mar. Biol. Lab., VIII, 1 (1960)
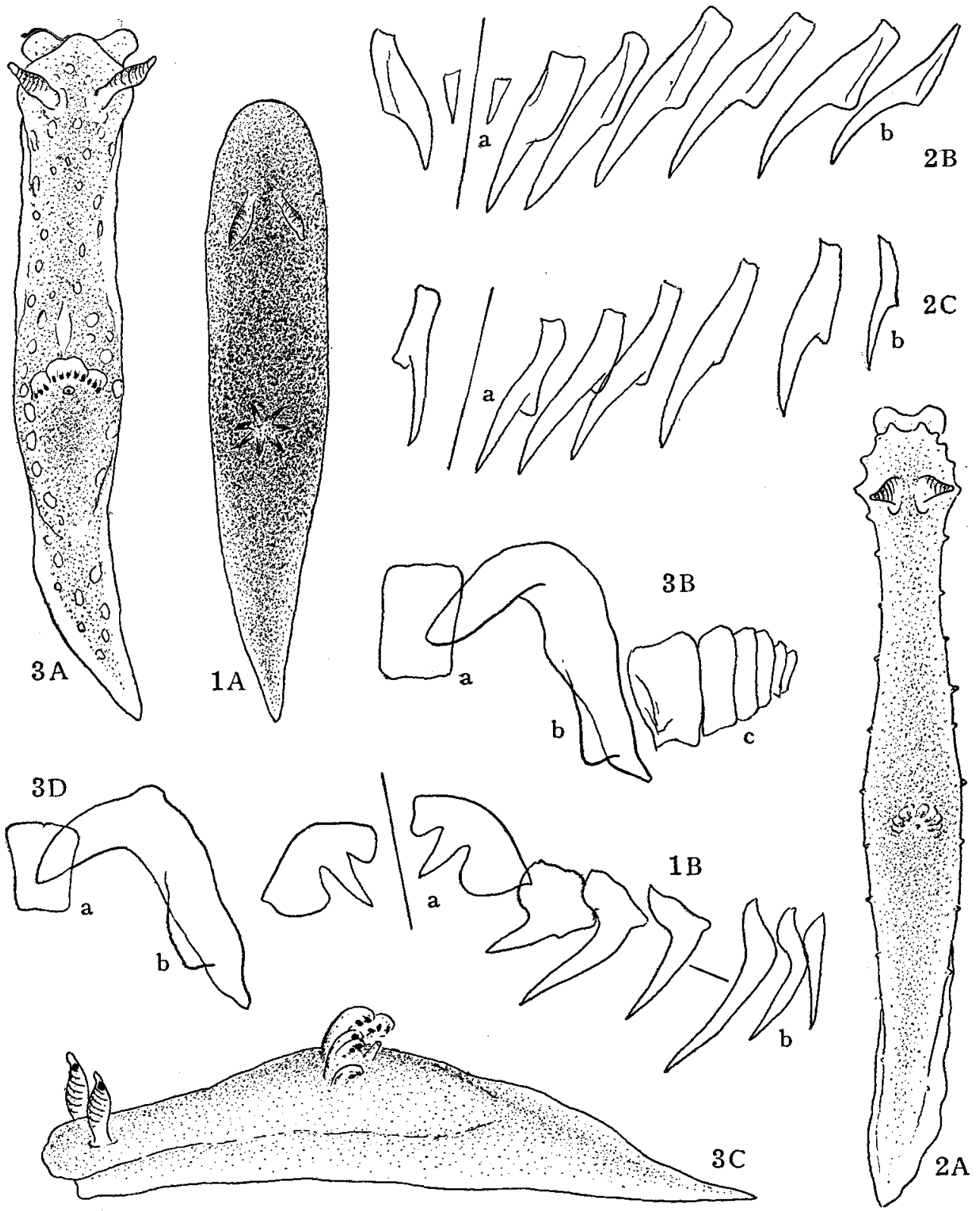

K. Baba: The Genera Gymodoris and Nembrotha from Japan. 